Research Article

\title{
Rainfall Erosion Predictions for Artificial High-Filled Embankment with Reinforcement
}

\author{
Shangwei Wu $\mathbb{D},{ }^{1}$ Dongming Wu $\mathbb{D},{ }^{2}$ Xiaofei Jing $\mathbb{D}^{1},{ }^{1}$ Xuanyi Chen $\mathbb{D}^{1},{ }^{1}$ Yijun Wang, \\ and Luhua Ye $\mathrm{Y}^{1}$ \\ ${ }^{1}$ School of Safety Engineering, Chongqing University of Science and Technology, Chongqing 401331, China \\ ${ }^{2}$ Jinzhu Subsidiary Company of Zhejiang Communications Construction Group Co Ltd, Hangzhou, China \\ Correspondence should be addressed to Dongming Wu; wdm94124@163.com and Xiaofei Jing; xfjing@cqust.edu.cn
}

Received 24 June 2021; Accepted 25 August 2021; Published 8 September 2021

Academic Editor: Song Jiang

Copyright (C) 2021 Shangwei Wu et al. This is an open access article distributed under the Creative Commons Attribution License, which permits unrestricted use, distribution, and reproduction in any medium, provided the original work is properly cited.

In recent years, rainstorm disasters caused by global warming have frequently occurred in China. It has caused serious damage to artificial high embankments. In this paper, the influence of rainfall intensity, slope, and reinforced layers on the erosion and destruction of the artificial high embankment is deeply analyzed. Through the model test, the rainfall erosion prediction model is established. The results show that (1) the gully width, depth, and erosion amount increased with the increase in rainfall intensity and slope and decreased with the increase in reinforcement layers; (2) the final ditch shape of the embankment is influenced by steel bars; and (3) according to the model test data, the mathematical model of dike scouring is established. Rainfall intensity and the coupling between slope and reinforced layers are considered in the model. It can be used for predicting erosion during rainfall.

\section{Introduction}

In recent years, there have been many rainstorms in China that are affected by global warming. Especially in the south of China in 2020, a large number of floods, mudslides, and landslides were caused by rainfall. The rainfall in Chongqing is $19 \%$ higher than the previous average level [1]. Due to the construction of a ground transportation network in Southwest China, a large number of artificial high embankments have been formed. In this case, deformation, instability, landslides, and other accidents are easy to occur.

In the past, $80 \%$ of landslide accidents were caused by rainfall. Therefore, many scholars have done a lot of research on rainfall. Some scholars analyzed the erosion effect of different rainfall modes and types on embankments [2-5]. The influence of rainfall intensities on sediment yield and embankment stability was also studied [6-8]. The results show that the greater the rainfall intensity is, the greater the sediment yield is, the greater the displacement is, and the lower the stability of the embankment is. Some scholars have studied the influence of slope gradient on erosion failure.
The larger the slope is, the faster the runoff speed is and the greater the rainfall erosion is. The greater the slope is, the greater the influence of rainfall on slope erosion is [9-12]. When the slope gradient exceeds a certain value, the rainfall erosion of the embankment is inversely proportional to it. Many scholars have conducted a large number of experimental studies on the critical slope, and the results show that the critical slope range is $10^{\circ} \sim 45^{\circ}$ [13-15]. Due to the limitation of topography, the stability of some fill embankments is not high, and the reinforcement method is usually adopted to reinforce fill embankment. Because of this situation, many scholars have studied the impact of reinforcement on embankment erosion. The influence of different reinforcement materials and methods on the stability of subgrade was studied. The results show that reinforcement can improve the stability of embankment [16-19]. When the quantity of reinforcement materials changes in a certain range, the stability of the slope will be improved with the increase in the quantity. When the amount of reinforcement materials exceeds a certain value, it will not affect the stability of the slope $[20,21]$. 
The erosion process of reinforced embankment induced by rainfall is very complex, and the blocking rule of reinforced belts in the erosion process is unclear. The research on artificial embankment has been focused on rainfall and reinforcement (materials and methods) and achieved fruitful results. However, there are few research reports on erosion damage under the coupling condition of reinforcement and rainfall. Based on the test of rainfall erosion on the reinforced embankment, this paper deeply analyzed the influence of rainfall intensity, slope, and reinforcement layers on the erosion of artificial embankment and established a prediction model of rainfall erosion on the reinforced artificial embankment under multifactor coupling. The research results can provide a reliable scientific basis for effectively forecasting rainfall landslide disasters of the reinforced artificial high embankment and have important theoretical value.

\section{Model Test of Rainfall Erosion on the Reinforced High Embankment}

2.1. Testing Equipment. The model test equipment is a selfdesigned model test equipment for embankment rainfall, as shown in Figure 1. The model groove is tempered glass, and the geometric size is $2 \mathrm{~m} \times 0.6 \mathrm{~m} \times 0.5 \mathrm{~m}$ (length $\times$ width $\times$ height) After pretest, this size is large enough to avoid size influence. Above the model trough, the rainfall system is composed of a water supply system and sprinkler. The data monitoring system consists of the following parts: BX-2 resistance earth pressure sensor and vibrating wire pore water pressure sensor produced by Dandong Electronic Instrument Factory and TST3828EW dynamic strain gauge produced by Jiangsu Tate Electronic Equipment Manufacturing Co., Ltd. A high-resolution camera is arranged in front of the model tank to record the rainfall erosion process.

The glass fiber mesh material is selected to replace geogrid as the reinforcement material, and the reinforcement parameters are shown in Table 1.

A series of rainfall erosion tests were carried out with different reinforcement layers $(N=0,1,2$, and 4 , as shown in Figure 2).

We analyzed the rainfall uniformity in which the rainfall uniformity can be calculated as follows:

$$
U=1-\frac{\sum\left(R_{i}-\bar{R}\right)}{n \bar{R}} .
$$

In the formula, $U$ is the rainfall uniformity; $R_{i}$ is the rainfall of rainfall range point $i$ within the test time; $n$ is the number of test points; and $R$ is the average rainfall of all test points within the rainfall range. As shown in Figure 3(a), 47 cups are evenly placed in the test glass tank, and the rainfall of each cup is collected at a rainfall duration of $60 \mathrm{~s}$ to calculate the uniformity. The results are shown in Figure $3(\mathrm{~b})$, and the results show that the uniformity meets the requirements of the rainfall test.

2.2. Experimental Materials and Procedures. To study the law of rainfall erosion damage to the embankment in the Chongqing area, referring to the previous research progress of embankment in Chongqing [22, 23], combined with the actual project in Chongqing, the test material was selected as the field clay of an embankment in Chongqing. After field sampling, the soil samples were dried and ground. The particle size distribution of soil samples was measured by the Winner3002 laser particle size analyzer. Other physical and mechanical parameters were obtained based on field data (Table 2). The final embankment model is $1.2 \mathrm{~m} \times 0.6 \mathrm{~m} \times 0.5 \mathrm{~m}$.

In the test, the model of reinforced embankment slope should be established first, and all sensors and reinforced belts should be installed completely. Then, rainfall is provided to the embankment through the rainfall system. When the embankment slope is eroded and damaged, the current gully width and depth are measured.

The specific steps of the fill embankment model building are as follows:

(1) The soil with $10 \%$ water content was prepared according to the test requirements (as shown in Figure 4(a)). The water content is low, so we can observe the influence of rising water content on the soil.

(2) The layer compaction method was used for constructing embankment with each layer of $8 \mathrm{~cm}$ and the compactness of each layer of $85 \%$ (as shown in Figure $4(\mathrm{~b})) .85 \%$ is selected because, in the engineering background, the result of sampling from the site is $85 \%$. To restore the actual site, $85 \%$ is done.

(3) The reinforcement and sensors are laid down (as shown in Figure 4(c)).

(4) After the fill embankment model building is completed (as shown in Figure 4(d)), the camera is placed and calibrated.

The experimental model is established by layered compaction. The compacted soil sample of each layer is $8 \mathrm{~cm}$ high; it is divided into five floors. To ensure that the compaction degree of each layer is uniform and the end effect is minimized, the surface is burred after each layer is compacted. This operation enables the soil below to be better combined with the upper layer, thus preventing the filling embankment model from stratification. Each layer is rammed with the same quality hammer and from the same height down the same number of compaction. After compaction of each layer, four soil samples were taken from each layer by the ring knife for the density test. After the density test, the sampling vacancy is filled in the above manner. Finally, the soil volume is compared with the expected value through the overall measurement.

2.3. Test Scheme. The slope is made by the layer pressure method, and each layer is piled up into soil piles with the same height according to the same mass of samples, and the soil is compacted from the same height by the compaction 


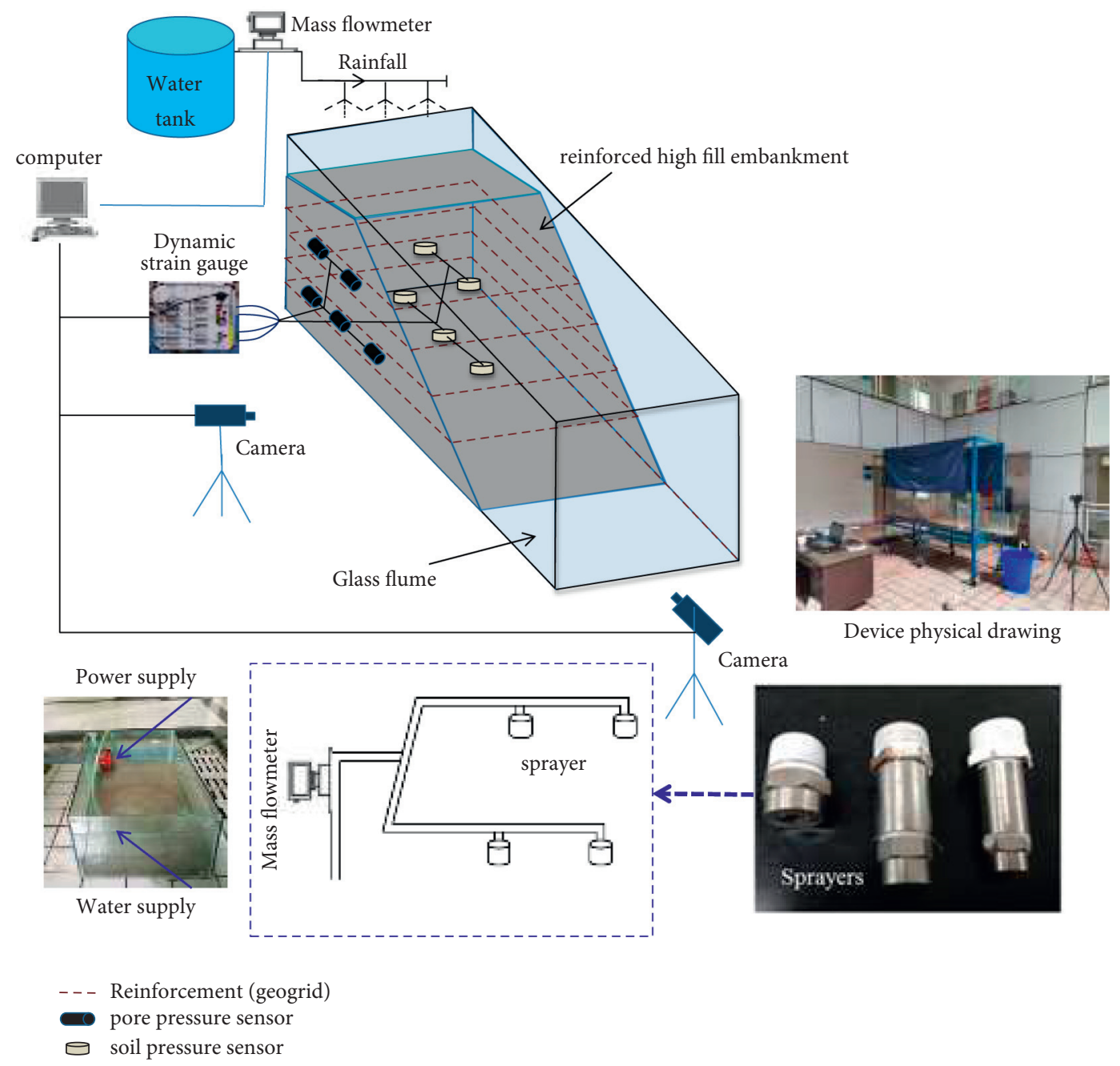

FIGURE 1: Rainfall test system for reinforced artificial high embankment.

TABLe 1: The basic property of reinforcement.

\begin{tabular}{lccc}
\hline \multirow{2}{*}{ Type } & \multicolumn{3}{c}{ Grid size $(\mathrm{mm})$} \\
& Vertical & Horizontal & Longt \\
\hline JT 11 01 & 25 & 25 \\
\hline & & \\
\hline
\end{tabular}

(a)

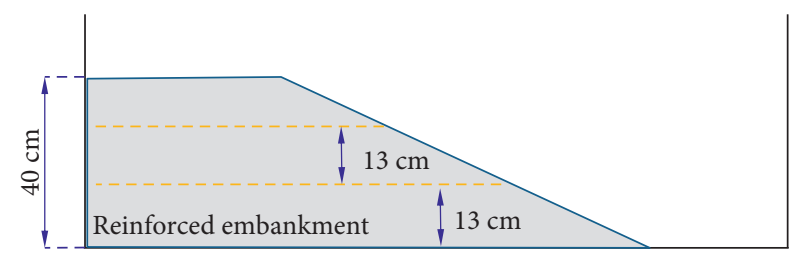

(c)

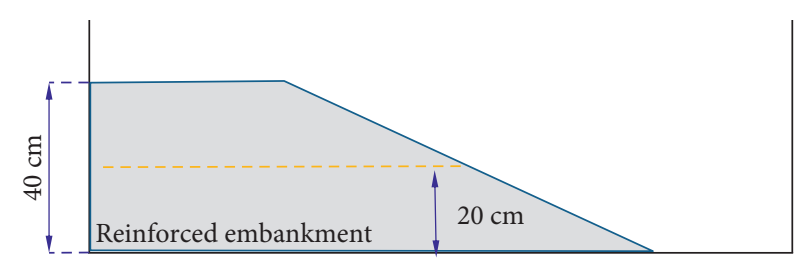

(b)

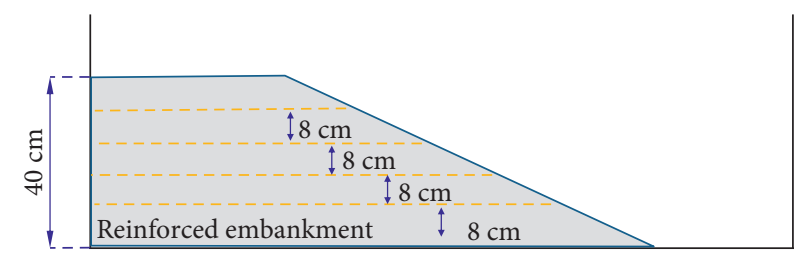

(d)

Figure 2: The schematic diagram of reinforcement layers: (a) $N=0$; (b) $N=1$; (c) $N=2$; (d) $N=4$. 


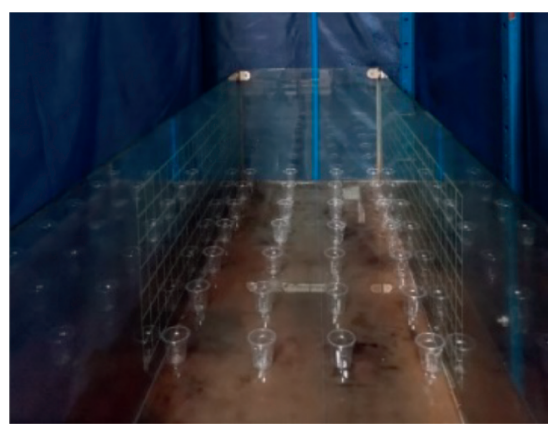

(a)

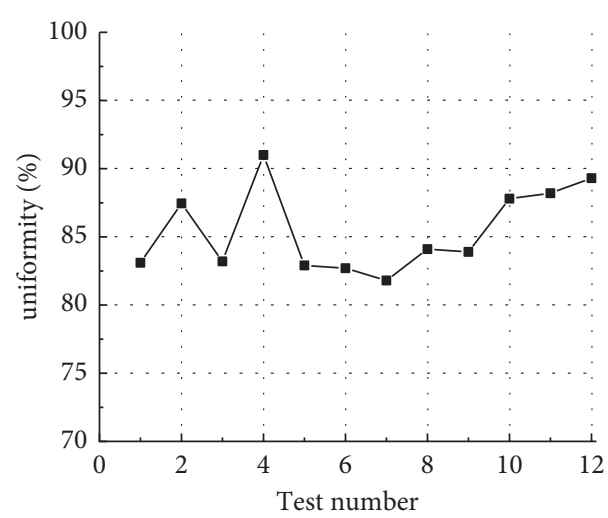

(b)

Figure 3: Rainfall dispersion test. (a) Rainfall dispersion experiment. (b) The uniformity of each test.

TABle 2: Physical and mechanical parameters of test soil.

\begin{tabular}{lr}
\hline Index & Values \\
\hline Sample layers $\left(\mathrm{g} / \mathrm{cm}^{3}\right)$ & 1.75 \\
Median diameter $D_{50}(\mathrm{um})$ & 6.42 \\
Water content $(\%)$ & 16.8 \\
Cohesion $(\mathrm{kPa})$ & 21.5 \\
Internal friction angle $\left(^{\circ}\right)$ & 20.16 \\
Poisson ratio & 0.254 \\
\hline
\end{tabular}

hammer with the same mass. To ensure the uniformity of soil compaction, a square board is placed under the hammer. After each layer is laid, the ring cutter is sampled, the ring cutter quality is weighed, and the degree of compaction is detected. The top surface of each layer adopts the method of hearing so that the soil can be more closely combined with the upper layer of soil to avoid the end effect between the layers. Finally, the built slope is cut to different angles under the same degree of compaction.

Based on the average rainfall of Chongqing in recent 50 years and rainfall strength of each return period [24], the setting values of rainfall intensity variables are $14,28,42$, and $70 \mathrm{~mm} / \mathrm{h}$; in line with the actual situation of the Chongqing area, the setting values of slope gradient variables are 30, 35, 40 , and $45^{\circ}$; according to the size of the indoor test model, the band layers variables are designed as $0,1,2$, and 4 layers, and the fill embankment model is constructed for the indoor artificial rainfall test. Specific programs are as shown in Table 3.

\section{Analysis of Model Test Results}

To analyze the slope failure of reinforced artificial high-fill embankment under rainfall, the effects of rainfall intensity, slope gradient, and reinforcement layers on the development of gully on the slope were analyzed. The width and depth of the main gully on the slope were measured by the ruler method and the photography method. The main source of embankment slope erosion is gully erosion, and gully development can characterize the total erosion degree.
3.1. Influence of Rainfall Intensity on Erosion Damage of Embankment. As shown in Figure 5, with a slope gradient of $45^{\circ}$, the 2-reinforced layer is the basic test condition, and different rainfall intensities $(14,28,42$, and $70 \mathrm{~mm} / \mathrm{h})$ are the influencing factors. After 90 minutes of rainfall, erosion and damage of embankment were observed. The results show that with the increase in rainfall intensity, the width and depth of the gully on the embankment slope increased significantly, and the amount of soil loss also increased. The main reason is that the rainfall power increases, the runoff erosion is formed earlier, the runoff velocity increases, and the erosion on the embankment slope increases significantly.

With continuous rainfall, the width and depth of the maximum gully on the slope are measured every 10 minutes. Under the influence of rainfall intensity $(14,28,42$, and $70 \mathrm{~mm} / \mathrm{h}$ ), the development trend of the embankment gully is shown in Figure 6. It can be seen from the diagram that rainfall strength has a significant impact on the erosion damage of artificial embankments. With the increase in rainfall intensity, the width and depth of the gully and the amount of erosion are increasing. As rainfall intensity increased from $14 \mathrm{~mm} / h$ to $70 \mathrm{~mm} / h$, gully width increased by $13.0 \mathrm{~cm}$, depth increased by $8.1 \mathrm{~cm}$, and erosion increased by $22.0 \mathrm{~kg}$. The main reason is that rainfall intensity increases, the rainfall erosion force increases, and the embankment erosion is more intense.

3.2. Influence of Slope Gradient on Embankment Erosion Damage. As shown in Figure 7, the experimental conditions are as follows: rainfall intensity is $42 \mathrm{~mm} / \mathrm{h}$. Two layers of 


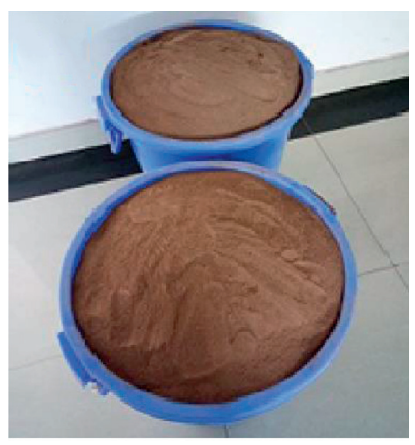

(a)

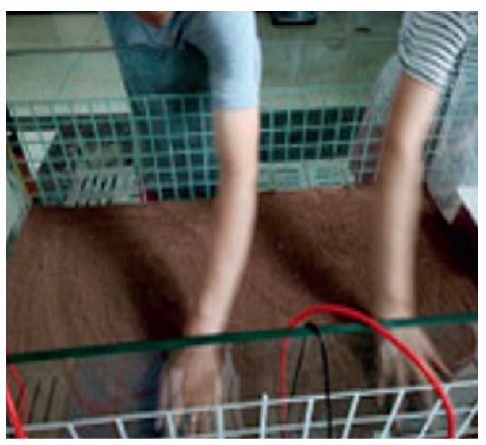

(b)

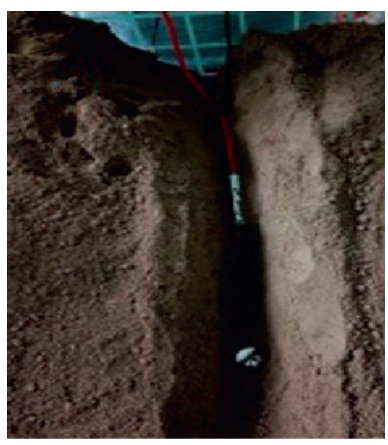

(c)

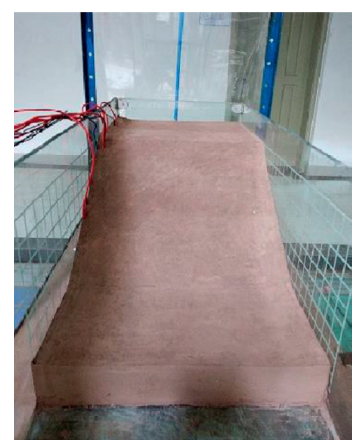

(d)

Figure 4: Establishment process of experimental soil sample: (a) soil sample; (b) fill embankment construction; (c) fill embankment construction; (d) final model.

TABle 3: Test scheme.

\begin{tabular}{lccc}
\hline Test variables & Rainfall intensity $(\mathrm{mm} / \mathrm{h})$ & Slope gradient $\left(^{\circ}\right)$ & Reinforcement layers $($ layers $)$ \\
\hline \multirow{3}{*}{ Factor level } & 1.4 & 3.0 & 0 \\
& 2.8 & 3.5 & 1 \\
& 4.2 & 4.0 & 2 \\
& 7.0 & 45 & 4 \\
\hline
\end{tabular}

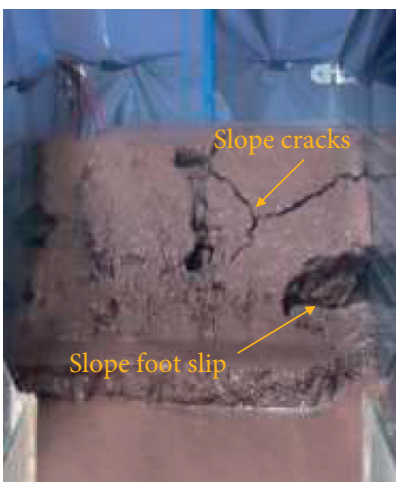

(a)

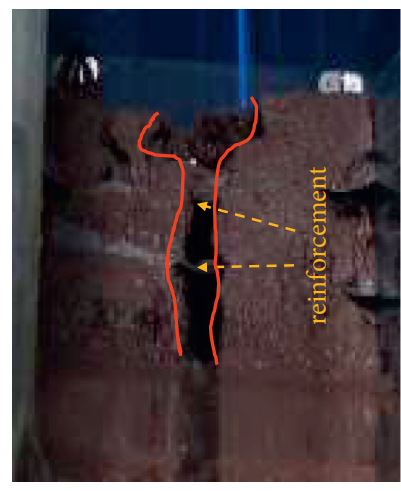

(b)

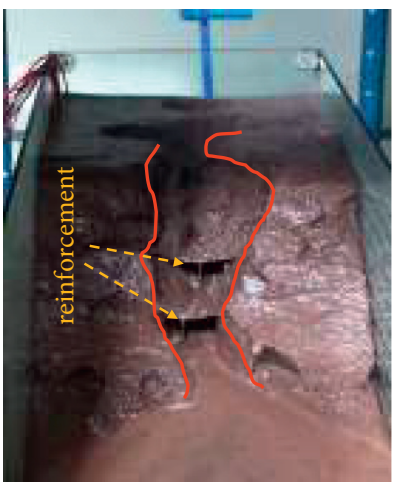

(c)

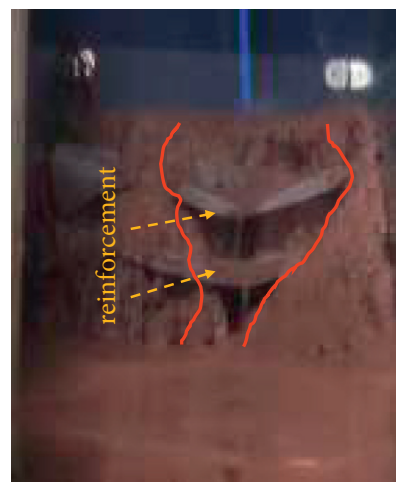

(d)

FiguRe 5: Final erosion failure of reinforced embankment under different rainfall intensities: (a) $14 \mathrm{~mm} / \mathrm{h}$; (b) $28 \mathrm{~mm} / \mathrm{h}$; (c) $42 \mathrm{~mm} / \mathrm{h}$; (d) $70 \mathrm{~mm} / \mathrm{h}$.

geogrid shall be laid in the soil. Under the influence of different slopes $(30,35,40$, and 45$)$, the ultimate erosion damage after rainfall which lasts for 90 minutes is observed. The results show that the greater the embankment slope, the more serious the soil erosion, and the larger the sliding area, the more serious the soil erosion. The main reason is that with the increase in slope gradient, the gravity component of soil in the slope direction increases, which leads to the decline of the stability of the slope soil. The runoff speed increases with the increase in slope so do rainfall erosion on the slope.

Figure 8 shows the development trend of dikes and ditches under the influence of slope. It can be seen from the figure that the embankment slope has a significant influence on the erosion and damage of artificial embankments. With the increase in slope gradient, the gully width, depth, and erosion amount increase. When the slope gradient increased from $30^{\circ}$ to $45^{\circ}$, the gully width increased by $4.8 \mathrm{~cm}$, the depth increased by $4.5 \mathrm{~cm}$, and the erosion amount increased by $4.8 \mathrm{~kg}$. The main reason is that the slope gradient increases, the slope runoff velocity increases, and the erosion of rainfall on the embankment increases.

3.3. Influence of Reinforcement Layers on Embankment Erosion Damage. As shown in Figure 9, under the experimental conditions of rainfall intensity of $42 \mathrm{~mm} / \mathrm{h}$, the slope of 45 , and different reinforcement layers $(0,1,2,4)$, the final erosion failure phenomenon of rainfall lasts $90 \mathrm{~min}$. The phenomenon shows that the width and depth of the gully decrease significantly with the increase in reinforcement layers. The main reason is the combination of reinforcement 


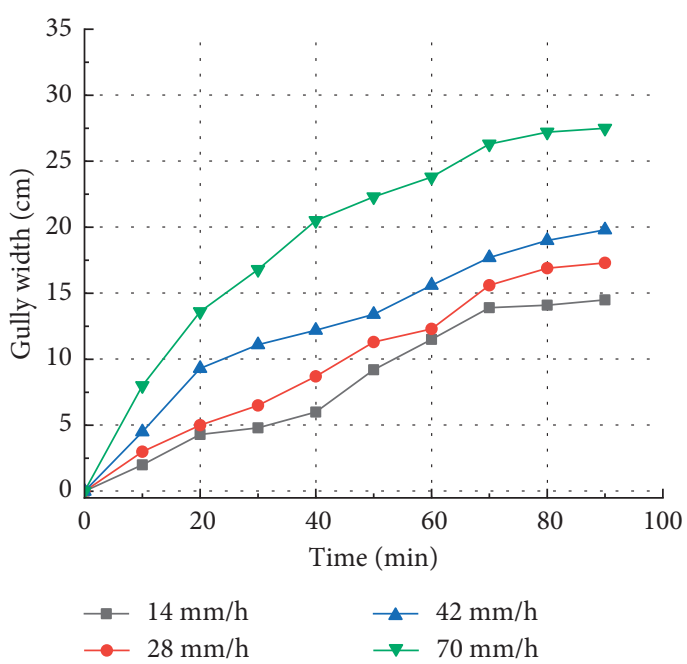

(a)

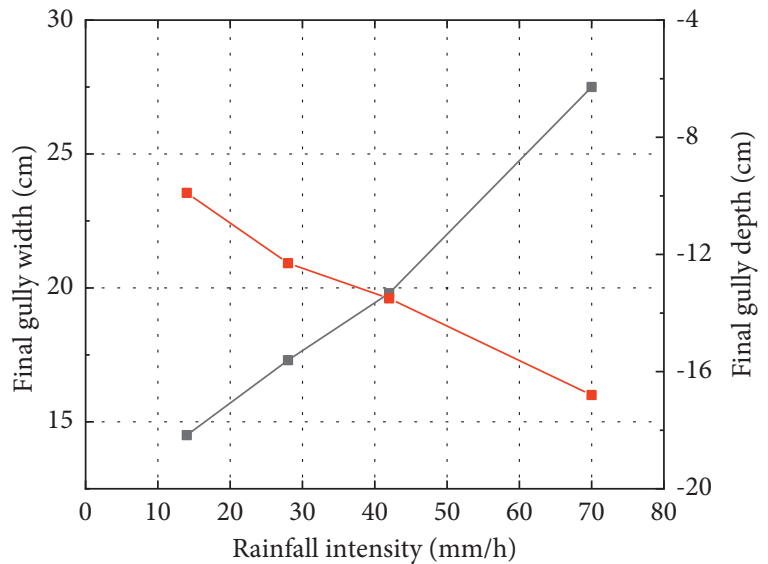

Final gully width

- Final gully depth

(c)

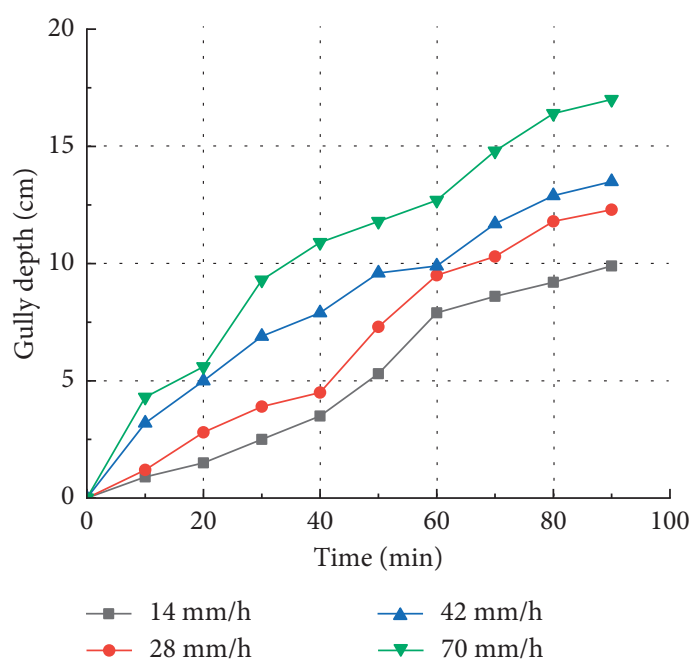

(b)

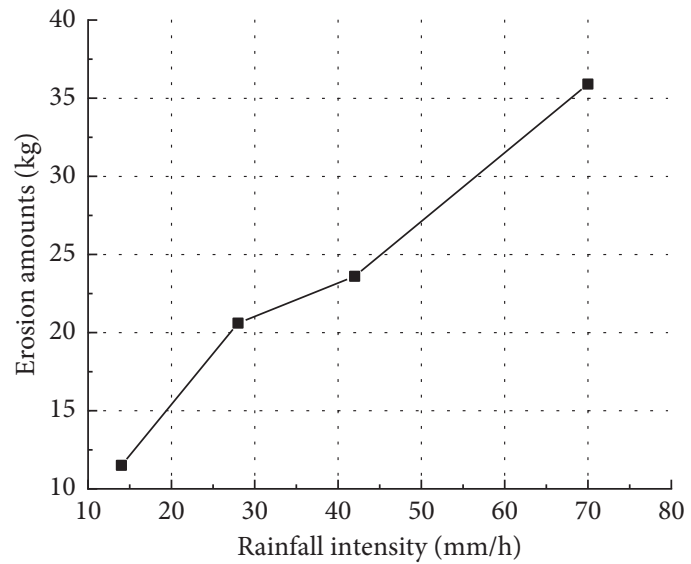

(d)

FiguRE 6: Effect of embankment erosion under different rainfall intensities: (a) gully width changes with time; (b) gully depth changes with time; (c) final gully width and depth; (d) final erosion amount.

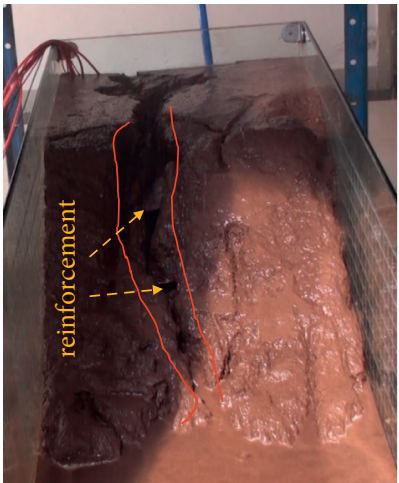

(a)

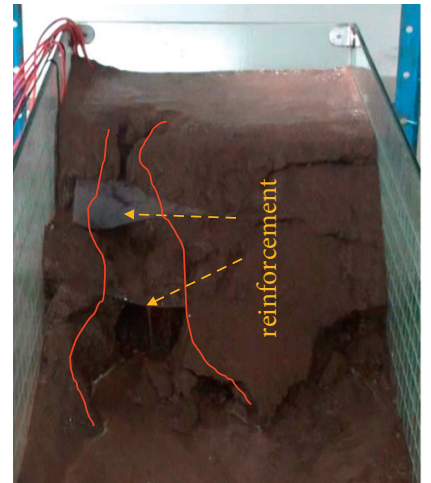

(b)

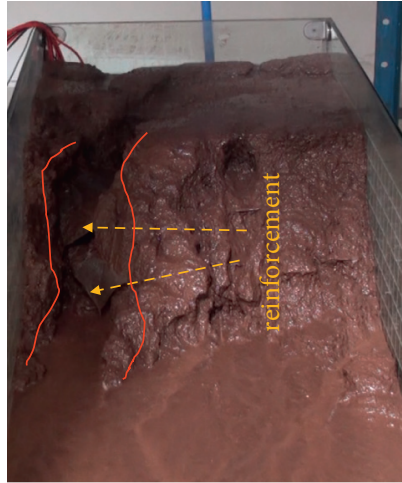

(c)

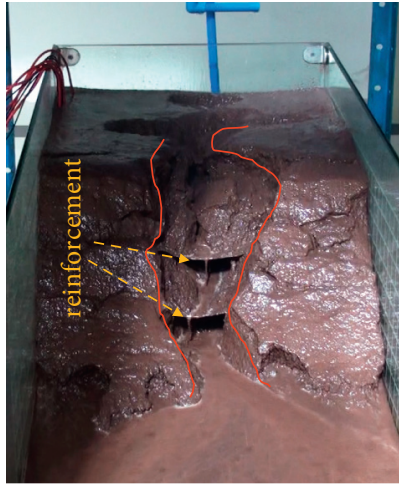

(d)

FIgURE 7: Final erosion failure of reinforced embankment with different slope gradients: (a) $30^{\circ}$; (b) $35^{\circ}$; (c) $40^{\circ}$; (d) $45^{\circ}$. 
and soil, which improves the strength of the embankment. With the increase in the number of geogrid layers, the interaction between adjacent layers increases significantly. Thus, the erosion of rainfall on the embankment slope is effectively reduced. When the gully develops to the rib zone, the flow does not damage the rib zone, and it will flow down the rib zone. At this time, the flow passing through the rib zone will be divided into two parts. One part is the seepage water. It penetrates the slope directly through the reinforcement belt, softening the subsoil and reducing the strength of the soil. The other part is the runoff water. It formed along the band breaks the surface. The soil is constantly eroded, and finally a gully with holes is formed on the slope.

Figure 10 is the final erosion damage consequence of embankment under different reinforcement densities $(0,1$, 2 , and 4 layers). It can be seen from the figure that the reinforcement layers have a significant impact on the gully width of an artificial embankment. The larger the number of reinforcement layers added to the filled embankment is, the smaller the erosion damage consequence under rainfall is. The test shows that when the reinforcement layers increase from 0 layers to 4 layers, the gully width per unit time decreases by $14.5 \mathrm{~cm}$, the depth decreases by $11.5 \mathrm{~cm}$, and the erosion amount decreases by $13.8 \mathrm{~kg}$.

\section{Study on Prediction Model of Rainfall Erosion Damage to Reinforced High- Fill Embankment}

To discuss the coupling effect of rainfall intensity, reinforced layer, and reinforcement layers on the consequences of rainfall erosion damage to reinforced high-fill embankment, the influence of each factor on the consequences of erosion disaster is analyzed. The relationship between the factor and the final results is obtained. Based on the function form, the function form of the coupling prediction model is determined, and then the parameters are determined.

\subsection{Study on the Influence of Various Factors on the Consequences of Erosion Damage}

4.1.1. Effects of Rainfall Intensity on the Consequences of Erosion Disasters. Many scholars have also studied the relationship between rainfall intensity and embankment erosion damage, including Shen et al. [14], Jiang et al. [25], Qin et al. [26], and Chen [27]. Based on the rainfall model test, it is found that the amount of soil erosion increases with the increase in rainfall strength. Based on the model test results, the influence function of rainfall intensity on the consequences of erosion disaster is fitted, as shown in Table 4 . The results show that with the increase in rainfall intensity, gully width, gully depth, and erosion amount increase in a power function.

4.1.2. Effect of Slope Gradient on Erosion Disaster Consequences. Referring to previous studies, it is found that the influence of slope on soil erosion was also different. Chen et al. [28] found that the influence of slope on sediment yield was quadratic. Shen et al. [14] and Sheng et al. [29] found that the influence of slope on soil erosion was power function. As shown in Table 5, the influence of slope gradient change on the consequences of rainfall erosion disaster presents that with the increase in slope gradient, the gully width, gully depth, and erosion amount increase in a power function.

4.1.3. Effect of Reinforcement Layers on the Consequence of Erosion Disaster. Because there is little research on reinforced embankments in the past, there is no literature pointing out the functional relationship between the influence of reinforced layers on the consequences of erosion disasters. However, some scholars pointed out that the reinforcement effect of reinforcement materials on the fill embankment has an upper limit [20]. On this basis, we believe that with the increase in the number of reinforcement layers, the trench width, trench depth, and erosion amount decrease in a quadratic polynomial. The influence of the number of reinforcement layers on the consequences of erosion disasters is shown in Table 6. With the increase in the number of reinforcement layers, the trench width, trench depth, and erosion amount show a nonlinear decreasing trend.

\subsection{Study on Prediction Model of Rainfall Erosion Damage to} Reinforced High-Fill Embankment. The function model considers the influence of the above factors on the consequences of erosion disaster. The coupling prediction model with rainfall intensity, slope gradient, and reinforcement layers as independent variables and gully width and depth as the consequences of erosion disasters was fitted by IBM SPSS Statistics 26 (2).

According to the output results of SPSS software, the prediction model of rainfall erosion disaster of fill embankment is as follows:

Gully width:

$$
\begin{aligned}
L & =0.088 t Q^{0.519} S^{0.840}\left(-0.038 N^{2}-0.022 N+1.247\right), \\
R^{2} & =0.829 .
\end{aligned}
$$

Gully depth:

$$
\begin{aligned}
H & =0.353 t Q^{0.414} S^{0.494}\left(-0.009 N^{2}-0.100 N+0.923\right), \\
R^{2} & =0.917 .
\end{aligned}
$$




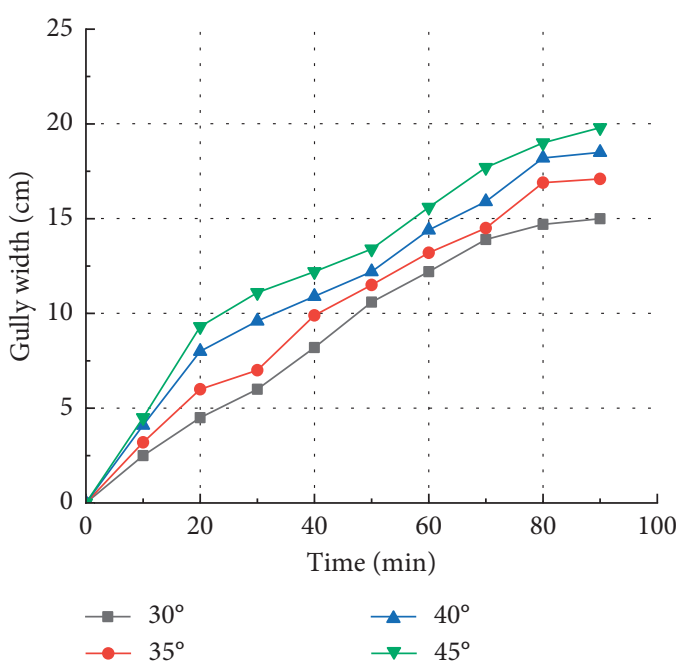

(a)

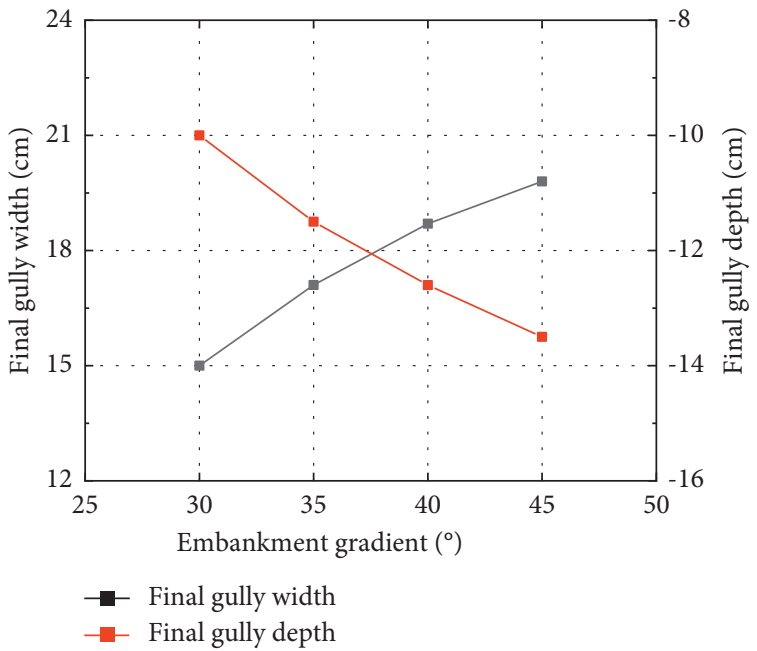

(c)

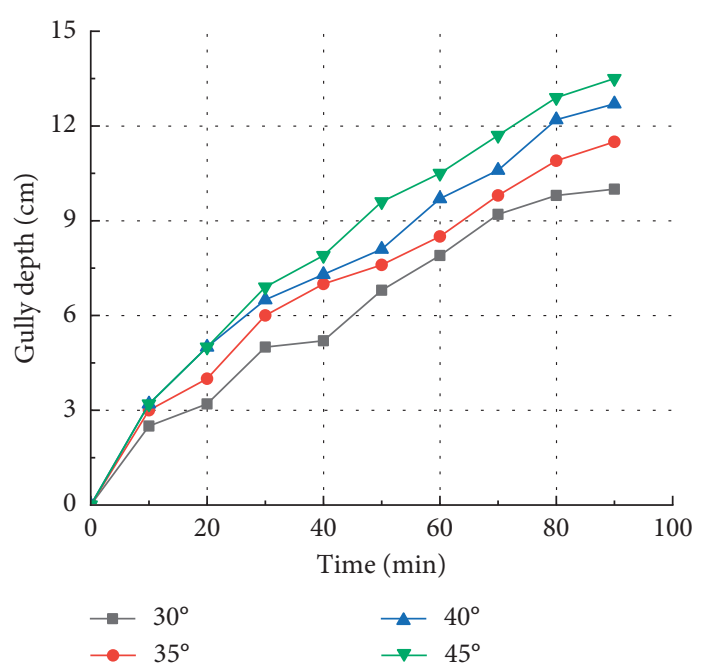

(b)

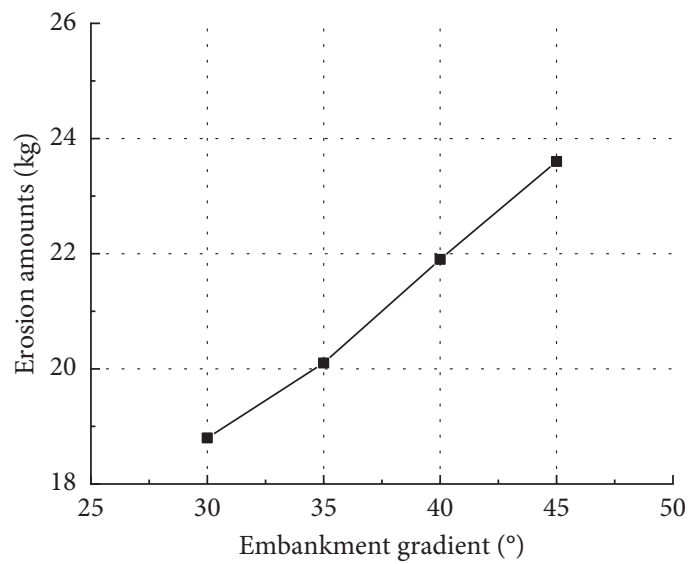

(d)

FIGURE 8: Effect of embankment erosion under different rainfall intensities: (a) gully width changes with time; (b) gully depth changes with time; (c) final gully width and depth; (d) final erosion amount.

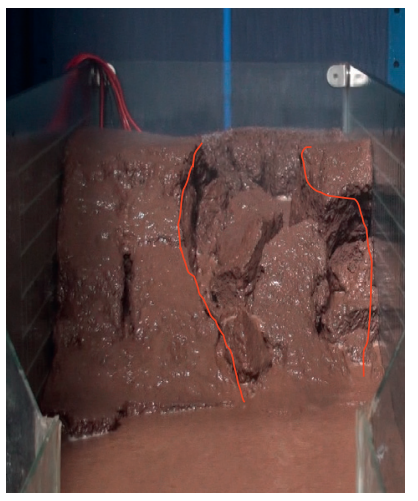

(a)

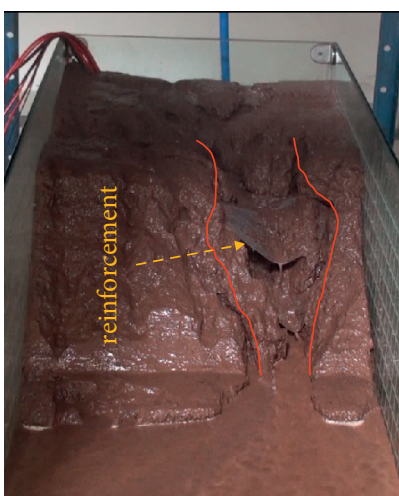

(b)

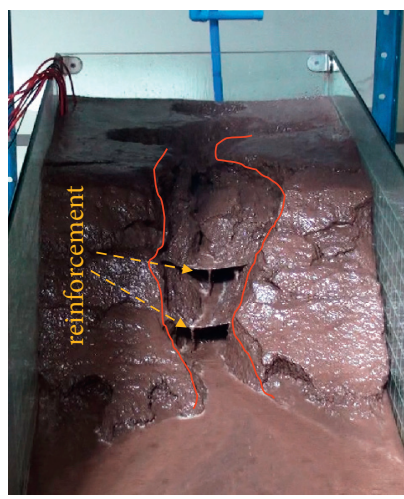

(c)

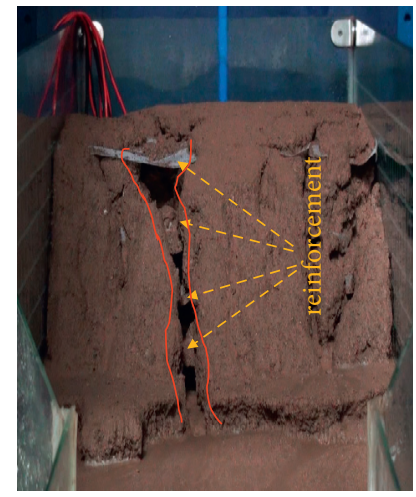

(d)

FIGURE 9: Erosion failure phenomena of different reinforcement layers: (a) $N=0$; (b) $N=1$; (c) $N=2$; (d) $N=4$. 


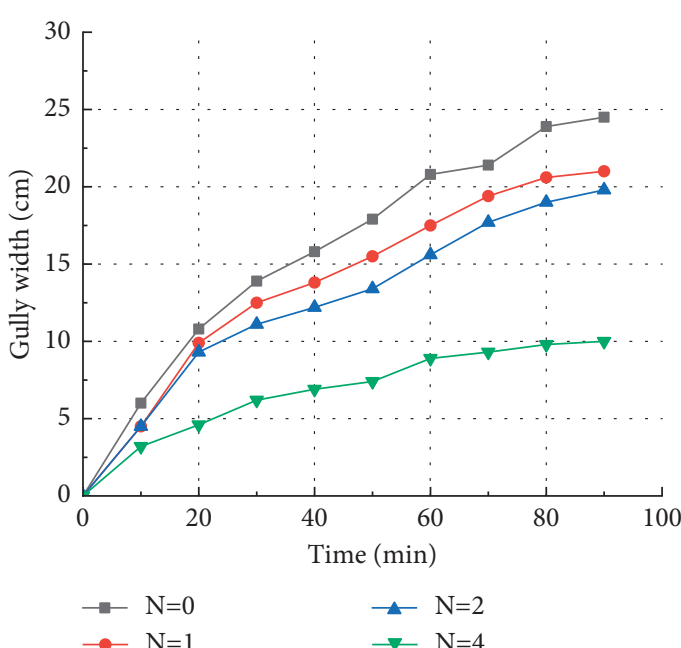

(a)

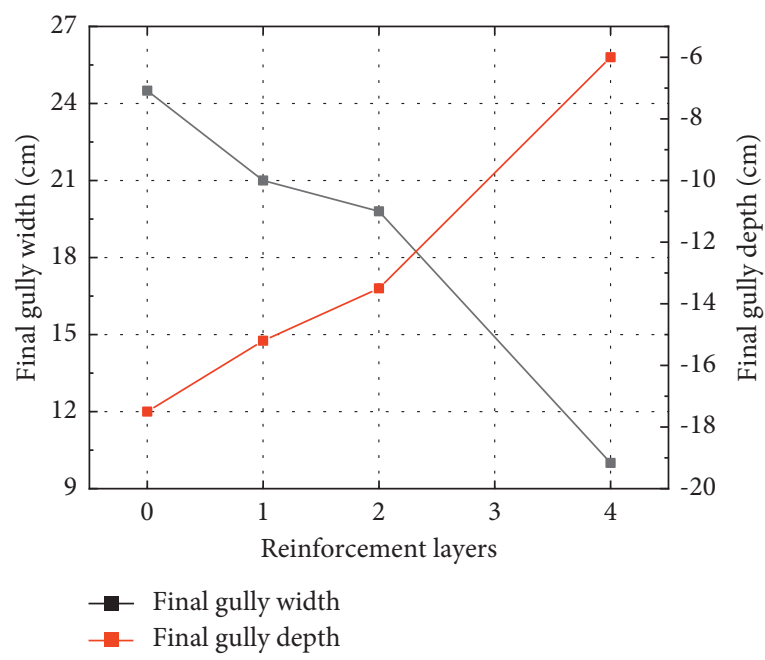

(c)

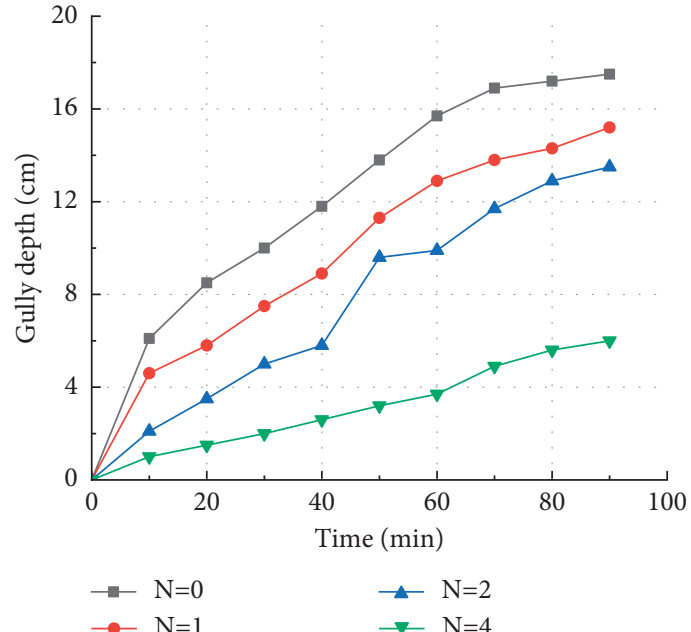

(b)

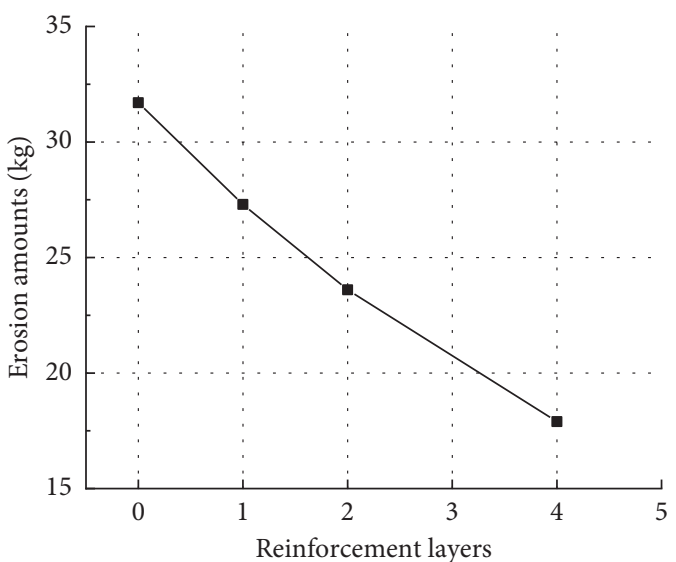

(d)

FIGURE 10: Erosion damage consequences of different reinforcement layers: (a) gully width changes with time; (b) gully depth changes with time; (c) final gully width and depth; (d) final erosion amount.

Erosion amounts:

$$
\begin{aligned}
& M=0.975 t Q^{0.698} S^{0.701}\left(-0.001 N^{2}-0.013 N+0.11\right), \\
& R^{2}=0.980 .
\end{aligned}
$$

$L$ is the gully width, $\mathrm{cm} ; H$ is the gully depth, $\mathrm{cm} ; M$ is the erosion amount, $\mathrm{kg} ; t$ is the rainfall time, hour; $Q$ is the rainfall intensity, $\mathrm{mm} / h ; S$ is the slope gradient, ${ }^{\circ}$; and $N$ is the reinforcement layers, layer.

It can be seen from the formula that with the increase in rainfall intensity and slope, the consequences of erosion disasters increase in the form of the power function. With the increase in the number of reinforcement layers, the consequences of the disaster decrease nonlinearly. The correlation coefficient $R^{2}$ of all formulas exceeds 0.80 , indicating that the obtained prediction model formula can accurately fit the results of the indoor model test.
4.3. Verification of Prediction Model of Rainfall Erosion Damage to Reinforced High-Fill Embankment. The data in reference [22] were chosen because they are similar to the experiment in this paper for comparison. In this paper, the rainfall erosion model test of reinforced embankment with similar test materials was also carried out, and the influence of different influencing factors on the erosion damage of embankment was obtained. However, the change of erosion amount was not involved in that paper. To ensure the consistency of the verification data, only the width and depth of the gully were verified but not the scouring amount. The main source of the slope erosion of the embankment was rill erosion, and the rill development could represent the total erosion development. Therefore, the accuracy of the prediction of gully development could roughly determine the accuracy of formulas (2)-(4). As shown in Figure 11, after the test conditions in reference [22] are substituted into the prediction model, the calculated gully width and depth are compared with their test 
TABLE 4: Effect of rainfall intensity on erosion disaster consequences.

\begin{tabular}{lcr}
\hline Influencing factor & Fitting equation of erosion consequence & Correlation coefficient \\
\hline & Gully width: $L=4.282 Q^{0.429}$ & $R^{2}=0.919$ \\
Rainfall intensity $(\mathrm{mm} / \mathrm{h})$ & Gully depth: $H=2.312 Q^{0.478}$ & $R^{2}=0.946$ \\
& Erosion amounts: $M=1.978 Q^{0.679}$ & $R^{2}=0.975$ \\
\hline
\end{tabular}

TABLE 5: Effect of slope gradient on erosion disaster consequences.

\begin{tabular}{lcr}
\hline Influencing factor & Fitting equation of erosion consequence & Correlation coefficient \\
\hline & Gully width: $L=1.565 S^{0.668}$ & $R^{2}=0.985$ \\
Slope gradient $\left({ }^{\circ}\right)$ & Gully width: $H=2.656 S^{0.3699}$ & $R^{2}=0.943$ \\
& Erosion amounts: $M=2.656 S^{0.573}$ & $R^{2}=0.988$ \\
\hline
\end{tabular}

TABLE 6: Effect of reinforcement layers on erosion disaster consequence.

\begin{tabular}{lcr}
\hline Influencing factor & Fitting equation of erosion consequence & Correlation coefficient \\
\hline & Gully width: $L=-0.475 N^{2}-1.595 N+24.11$ & $R^{2}=0.951$ \\
Reinforcement layers $(N)$ & Gully depth: $H=-0.370 N^{2}-1.339 N+17.33$ & $R^{2}=0.986$ \\
& Erosion amounts: $M=0.305 N^{2}-4.664 N+31.69$ & $R^{2}=0.998$ \\
\hline
\end{tabular}

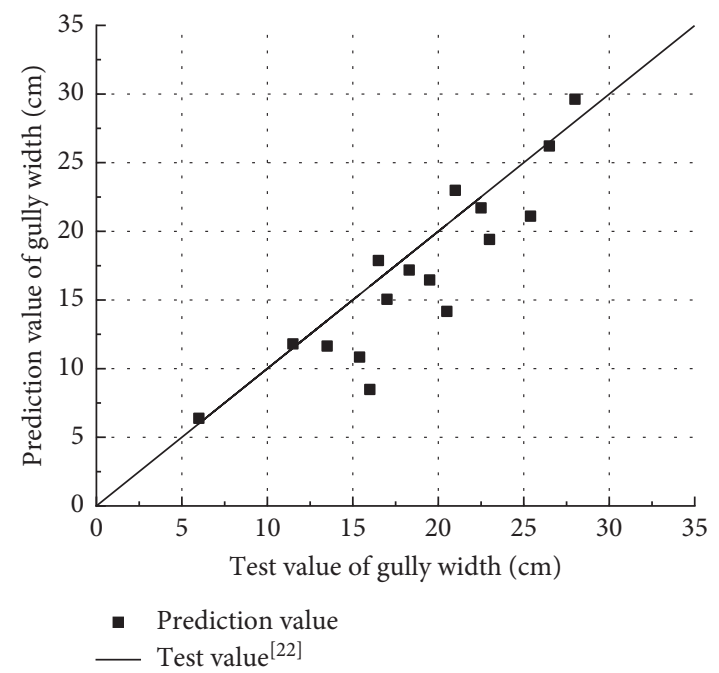

(a)

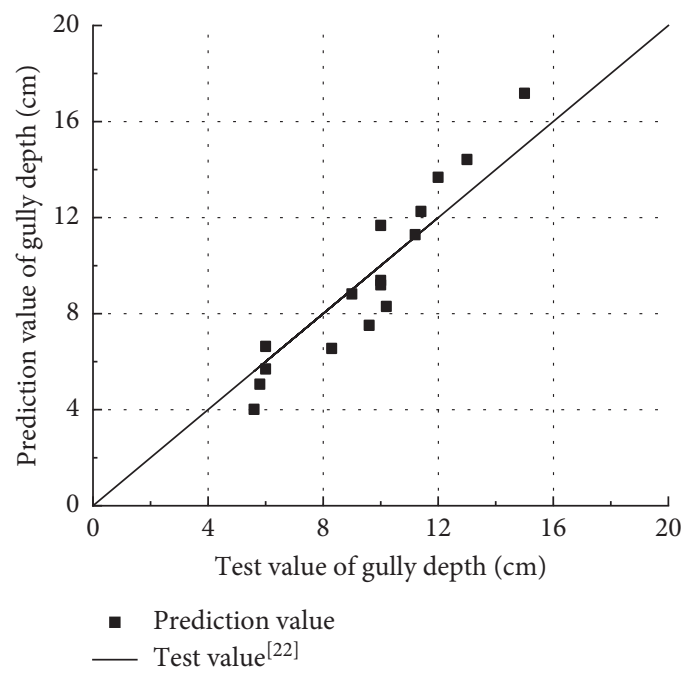

(b)

Figure 11: Verification and comparison of prediction models: (a) comparison of gully width; (b) comparison of gully depth.

values. The scatter is the predicted value, the slant is the test value, and the distance between the scatter and the slant represents the error.

As shown in Table 7, the absolute error and relative error of prediction calculated by 16 groups of test conditions and test values in reference [22] are compared with the predicted data calculated by the model substituted for the test conditions. The absolute error and relative error of gully width predicted by the model are $2.72 \mathrm{~cm}$ and $16.6 \%$, respectively. The absolute error of gully depth is $1.15 \mathrm{~cm}$, and the relative error is $13.7 \%$. 
TABLE 7: Prediction error of erosion disaster consequence.

\begin{tabular}{lcc}
\hline Consequences of erosion disasters & Mean absolute error $(\mathrm{cm})$ & Mean relative deviation $(\%)$ \\
\hline Gully width & 2.72 & 16.6 \\
Gully depth & 1.15 & 13.7 \\
\hline
\end{tabular}

\section{Conclusions}

This paper takes the reinforcement of artificial high embankment in Chongqing as the research background. Through the combination of model test and theoretical analysis, a prediction model of rainfall erosion damage to reinforced high-fill embankment was established. The influence of rainfall intensity, slope, and reinforcement layer is considered in the model. Concrete conclusions are as follows:

(1) Adding a reinforced belt to fill the embankment will have an impact on the final shape of the ditch and form a stepped ditch on the slope. The more levels, the more meaningful the form.

(2) In the rainfall erosion for artificial high-filled embankment with reinforcement, the width, depth, and erosion amount of the gully increased with the increase in rainfall intensity and slope but decreased with the increase in reinforced layers. When rainfall intensity increased from $14 \mathrm{~mm} / \mathrm{h}$ to $70 \mathrm{~mm} / \mathrm{h}$, the ditch width increased by $13.0 \mathrm{~cm}$, the ditch depth increased by $8.1 \mathrm{~cm}$, and the erosion increased by 24.4 kilograms. When the embankment slope increases from 30 to 45 , the three elements increased by $4.8 \mathrm{~cm}, 4.5 \mathrm{~cm}$, and $4.8 \mathrm{~kg}$, respectively. When the reinforcement layers are increased from 0 to 4 layers, the three elements decreased by $14.5 \mathrm{~cm}, 11.5 \mathrm{~cm}$, and $13.8 \mathrm{~kg}$, respectively.

(3) A multifactor coupling rainfall erosion prediction model is put forward. With the increase in rainfall intensity and slope, the consequences of erosion disasters present a power function increasing trend. With the increase in the number of reinforcement layers, the consequence of erosion disaster decreases as a quadratic function.

\section{Data Availability}

The data used to support the findings of this study are available from the corresponding author upon request.

\section{Conflicts of Interest}

The authors declare that there are no conflicts of interest.

\section{Acknowledgments}

This research was funded by the National Natural Science Foundation of China (Nos. 51974051 and 51804051), the Natural Science Foundation Project of Chongqing Science and Technology Commission (No. cstc2018jcyjAX0231), the Self-Made Equipment Foundation of Chongqing University of Science and Technology (No. ZZSB2019013), and the Scientific and Technological Research Program of Chongqing Municipal Education Commission (No. KJZDK201901501).

\section{References}

[1] X. Yan, "China climate bulletin released in 2020: higher annual average temperature and more precipitation," 2021.

[2] W. S. d. Almeida, S. Seitz, L. F. C. d. Oliveira, and D. F. d. Carvalho, "Duration and intensity of rainfall events with the same erosivity change sediment yield and runoff rates," International Soil and Water Conservation Research, vol. 9, no. 1, pp. 69-75, 2021.

[3] L. Wu, M. Peng, S. Qiao, and X.-Y. Ma, "Effects of rainfall intensity and slope gradient on runoff and sediment yield characteristics of bare loess soil," Environmental Science and Pollution Research, vol. 25, no. 4, pp. 3480-3487, 2018.

[4] K. Christofer, R. Harianto, and S. Alfrendo, "Effect of variations in rainfall intensity on slope stability in Singapore," International Soil and Water Conservation Research, vol. 5, 2017.

[5] P. W. Zhong, H. L. Zhang, K. L. Tian, H. Chen, and K. Nie, "Study on the influence of continuous rainfall infiltration on the loess slope stability," Yellow River, vol. 40, no. 1, pp. 76-81, 2018.

[6] O. Augusto Filho and M. A. Fernandes, "Landslide analysis of unsaturated soil slopes based on rainfall and matric suction data," Bulletin of Engineering Geology and the Environment, vol. 78, no. 6, pp. 4167-4185, 2019.

[7] C. Anusron, H. Toshikazu, S. Hirotaka, S. Tomotaka, and K. Yuji, "Experimental tests of slope failure due to rainfalls using physical slope models," Soils and Foundations, vol. 58, no. 2, pp. 03-18, 2018.

[8] E. Elkamhawy, H. B. Wang, B. Zhou, and Z. Yang, "Failure mechanism of a slope with a thin soft band triggered by intensive rainfall," Journal of Environment and Earth Science, vol. 77, no. 9, pp. 1-15, 2018.

[9] S. E. Cho, "Stability analysis of unsaturated soil slopes considering water-air flow caused by rainfall infiltration," Engineering Geology, vol. 211, pp. 184-197, 2016.

[10] N. V. Sobol, I. M. Gabbasova, and M. A. Komissarov, "Effect of rainfall intensity and slope steepness on the development of soil erosion in the southern Cis-Ural region (a model experiment)," Eurasian Soil Science, vol. 50, no. 9, pp. 1098-1104, 2017.

[11] T. Li, L. Zhao, H. Duan, Y. Yang, Y. Wang, and F. Wu, "Exploring the interaction of surface roughness and slope gradient in controlling rates of soil loss from sloping farmland on the Loess plateau of China," Hydrological Processes, vol. 34, no. 2, pp. 339-354, 2020.

[12] E. Koomson, T. Muoni, C. Marohn, G. Nziguheba, I. Öborn, and G. Cadisch, "Critical slope length for soil loss mitigation in maize-bean cropping systems in SW Kenya," Geoderma Regional, vol. 22, 2020.

[13] D. Liu, D. She, S. E. Yu, G. Shao, and D. Chen, "Rainfall intensity and slope gradient effects on sediment losses and 
splash from a saline-sodic soil under coastal reclamation," Catena, vol. 128, pp. 54-62, 2015.

[14] H. O. Shen, F. L. Zheng, L. L. Wen, Y. Han, and W. Hu, "Impacts of rainfall intensity and slope gradient on rill erosion processes at loessial hillslope," Soil \& Tillage Research, vol. 155, 2016.

[15] X. Wang, Research on Slope Surface Erosion under a Rainfall of Artificially Loess Slope, Chang'a University, Xi'an, China, 2015.

[16] Y. H. Chok, M. B. Jaksa, W. S. Kaggwa, and D. V. Griffiths, "Assessing the influence of root reinforcement on slope stability by finite elements," International Journal of GeoEngineering, vol. 6, no. 1, 2015.

[17] D. Bhattacherjee and B. V. S. Viswanadham, "Effect of geocomposite layers on slope stability under rainfall condition," Indian Geotechnical Journal, vol. 48, no. 2, pp. 316-326, 2018.

[18] F. Zhang, D. Leshchinsky, Y. Gao, and S. Yang, "Corner reinforced slopes: r," Geotextiles and Geomembranes, vol. 47, no. 3, pp. 408-416, 2019.

[19] G. Zheng, X. Yu, H. Zhou, X. Yang, W. Guo, and P. Yang, "Influence of geosynthetic reinforcement on the stability of an embankment with rigid columns embedded in an inclined underlying stratum," Geotextiles and Geomembranes, vol. 49, no. 1, pp. 180-187, 2021.

[20] Lossanima, Centrifugal Model Test and Finite Element Analysis of Reinforced Soil Slope, Tsinghua University, Beijing, China, 2011.

[21] X. Jing, Y. Chen, D. Williams, M. Serna, and H. Zheng, "Overtopping failure of a reinforced tailings dam: laboratory investigation and forecasting model of dam failure," Water, vol. 11, no. 2, pp. 315-330, 2019.

[22] C. S. Pan, Study on Stability and Evaluation of Safety Influencing Factors of Reinforced Embankment under Heavy Rainfall, Chongqing University of Science and Technology, Chongqing, China, 2018.

[23] Y. F. Liu, "Experimental study on rheological properties of lateritic clay in chongqing," Pearl River, vol. 38, no. 8, pp. 42-45, 2017.

[24] Q. Guo, R. Li, J. Sun et al., "The calculated design rainstorm in the central districts of chongqing," Journal of Southwest University (Natural Science), vol. 39, no. 5, pp. 170-177, 2017.

[25] M. H. Jiang, J. S. XiE, W. M. Wang, R. Z. Huang, and Y. C. Yang, "Effects of different land use and different rainfall intensities on soil and water loss in northern Fujian province," Science of Soil and Water Conservation, vol. 10, no. 4, pp. 84-89, 2012.

[26] W. Qin, C. Q. Zuo, Q. H. Yan, Z. Wang, P. Du, and N. Yan, "Regularity of individual rainfall soil erosion in bare slope land of red soil," Transactions of the Chinese Society of Agricultural Engineering, vol. 31, no. 2, pp. 124-132, 2015.

[27] X. A. Chen, Study on Soil Erosion and Erosion Empirical Model in Hilly Loess Region on the Loess Plateau, Huazhong Agricultural University, Wuhan, China, 2010.

[28] J. J. Chen, L. Y. Sun, J. T. Liu, and Q. G. Cai, "Effects of slope gradients on rill erosion: study based on three-dimensional laser technology," Science of Soil and Water Conservation, vol. 11, no. 3, pp. 1-5, 2013.

[29] H. W. Sheng, Impacts of Soil Type and Slope Gradient on Sloping Sheet Erosion and Rill Erosion in Loess Region, Northwest A\&F University, Xianyang, China, 2016. 